\title{
DIVERSE EFFECTS OF PULSED ELECTRICAL STIMULATION ON CELLS - WITH A FOCUS ON CHONDROCYTE AND CARTILAGE REGENERATION
}

\author{
T. Ning ${ }^{1,2,5}$, K. Zhang ${ }^{1,3}$, B.C. Heng ${ }^{4}$ and Z. Ge ${ }^{1, *}$ \\ ${ }^{1}$ Department of Biomedical Engineering, College of Engineering, Peking University, Beijing 100871, China \\ ${ }^{2}$ Peking-Tsinghua Center for Life Sciences, Beijing, China \\ ${ }^{3}$ Chinese Academy of Sciences Investment Management Co., Ltd., Beijing, 100080, China \\ ${ }^{4}$ School of Stomatology, Peking University, Beijing 100081, Beijing, China \\ ${ }^{5}$ Academy for Advanced Interdisciplinary Studies, Peking University, Beijing, 100871, China
}

\begin{abstract}
Biological effects of pulsed electrical stimulation (PES) on cells and tissues have been intensively studied with the aim of advancing their biomedical applications. These effects vary significantly depending on PES parameters, cell and tissue types, which can be attributed to the diverse variety of signaling pathways, ion channels, and epigenetic mechanisms involved. The development of new technology platforms, such as nanosecond pulsed electric fields (nsPEFs) with finely tuned parameters, have added further complexity. The present review systematically examines current research progress in various aspects of PES, from physical models to biological effects on cells and tissues, including voltage-sensing domains of voltage-gated channels, pore formation, intracellular components/organelles, and signaling pathways. Emphasis is placed on the complexity of PES parameters and inconsistency of induced biological effects, with the aim of exploring the underlying physical and cellular mechanisms of the physiological effects of electrical stimulation on cells. With chondrogenic differentiation of stem cells and cartilage regeneration as examples, the underlying mechanisms involved were reviewed and analyzed, hoping to move forward towards potential biomedical applications. Hopefully, the present review will inspire more interest in the wider clinical applications of PES and lay the basis for further comprehensive studies in this field.
\end{abstract}

Keywords: Electrical stimulation, electric fields, chondrocytes, chondrogenic differentiation, cartilage, stem cells.

*Address for correspondence: Dr Zigang Ge, Department of Biomedical Engineering, College of Engineering, Peking University, Beijing, 100871, China.

Telephone number: +86 01062756736 Fax number:+8601062751812 Email: gez@pku.edu.cn

Copyright policy: This article is distributed in accordance with Creative Commons Attribution Licence (http://creativecommons.org/licenses/by-sa/4.0/).

\begin{tabular}{llll}
\hline & List of Abbreviations & Cx43 & connexin 43 \\
& & DNMT1 & $\begin{array}{l}\text { DNA methyltransferase 1 } \\
\text { extracellular-signal-regulated kinase }\end{array}$ \\
ADSCs & adipose-derived stem cells & ERK & Food and Drug Administration \\
AGG & aggrecan & FDA & fibroblast growth factor 2 \\
Bax & Bcl-2-associated X protein & FGF2 & glycosaminoglycan \\
Bcl-2 & B-cell lymphoma 2 & GAG & high-frequency transcutaneous \\
BMI & body mass index & h-TENS & electrical nerve stimulation \\
BMPs & bone morphogenetic proteins & & interferential current \\
BMSCs & bone marrow stromal cells & IFC & insulin-like growth factor II \\
CaM & calmodulin & IGF2 & interleukin \\
CaN-NFAT & calcineurin-nuclear factor of & IL & insulin receptor substrate \\
& activated T cell & IRS & low-frequency transcutaneous \\
cGMP & cyclic guanosine monophosphate & l-TENS & \\
COL II & collagen II & JNK & c-Jun N-terminal kinase \\
CVI & chronic venous insufficiency & &
\end{tabular}




\begin{tabular}{|c|c|}
\hline MAPK & mitogen-activated kinase \\
\hline MSCs & mesenchymal stem cells \\
\hline NEUROG2 & neurogenin 2 \\
\hline NMES & neuromuscular electrical stimulation \\
\hline NIN & $\begin{array}{l}\text { non-invasive interactive } \\
\text { neurostimulation }\end{array}$ \\
\hline $\mathrm{NO}$ & nitric oxide \\
\hline nsPEFs & nanosecond-pulsed electric fields \\
\hline $\mathrm{OA}$ & osteoarthritis \\
\hline PD-ECGF & $\begin{array}{l}\text { platelet-derived endothelial cell } \\
\text { growth factor }\end{array}$ \\
\hline PEG & polyethylene glycol \\
\hline PES & pulsed electrical stimulation \\
\hline PIP2 & $\begin{array}{l}\text { phosphatidylinositol } \\
\text { 4,5-bisphosphate }\end{array}$ \\
\hline ROS & reactive oxygen species \\
\hline snRNPs & $\begin{array}{l}\text { small nuclear ribonucleoprotein } \\
\text { particles }\end{array}$ \\
\hline TGF- $\beta$ & transforming growth factor beta 1 \\
\hline VEGF & vascular endothelial growth factor \\
\hline VOCCs & voltage-operated calcium channels \\
\hline VSDs & voltage-sensing domains \\
\hline
\end{tabular}

Introduction

PES has long been studied in the context of clinical therapy for various diseases, including wound healing (Ud-Din and Bayat, 2014), bone and cartilage regeneration (Chao and Inoue, 2003; Ciombor and Aaron, 2005), recovery of motor neurons (Rossini et al., 2015), contractile properties of infarcted heart tissues (Hirt et al., 2014), and rehabilitation of muscle contractile function (Kern et al., 2016), as well as tumor therapy through triggering permanent membrane lysis or loss of homeostasis (Cemazar et al., 2013). Several PES devices have been approved by the US FDA for use in the treatment of various conditions, such as tumors, arthritis, and pain, with durations varying from $\mu$ s to ms (Table 1). Accumulation of Joule heating energy is still a major hurdle for clinical application of electrical stimulation (Voldman, 2006; Weaver et al., 1999), which in turn demands critical restrictions on PES parameters, even though mammalian cells can survive up to a $1-3{ }^{\circ} \mathrm{C}$ increase in temperature. Relatively broad or unfocused biological targets limit the exploration of the mechanistic effects of electrical stimulation, as well as their widespread applications in clinical therapy (Okino and Mohri, 1987; Yao et al., 2009). Some reviews have also focused on treatment of conditions such as OA, fracture healing, and muscle pain by PES (Ebrahim et al., 2014; Negm et al., 2013). PES has also been used for plant and animal tissue drying processes and food preservation (Toepfl et al., 2006). Furthermore, high intensity PES can be used as a highly effective process for decontamination of liquid food (Sobrino-López and Martín-Belloso, 2010).

The application of PES, with varying parameters, may lead to significantly varied outcomes under different physiological conditions (depending on cell phenotypes, attachment, and extracellular environment), which limits wider biomedical useage. For example, PES with voltages $\geq 3 \mathrm{~V}$ and frequencies $\geq 130 \mathrm{~Hz}$ has been reported to ameliorate Parkinson's disease, while PES with a frequency of $5 \mathrm{~Hz}$ significantly worsens akinesia (Moro et al., 2002). PES has been reported to prevent atrophy of long-term denervated muscles, resulting in increased muscle cross-sectional area (Ashley et al., 2007). On the other hand, PES (frequency of $20 \mathrm{~Hz}$ and durations longer than $2 \mathrm{~ms}$ ) can also lead to atrophy of muscle fibers in rats after immediate sciatic nerve injury, with a decrease in muscle excitability (Gigo-Benato et al., 2010).

Various methods have been used to apply PES both in vitro and in clinical practice (Fig. 1) (Balint et al., 2013; Griffin and Bayat, 2011). The simplest way to apply PES is to arrange that electrodes are in direct contact with cells cultured in vitro (Fig. 1a). However, some by-products such as ROS could be detrimental. Capacitive coupling for in vitro experiments consists in subjecting cells in a Petri dish to two parallel layers of electrode plates (Fig. 1b). Such an approach can generate a homogenous electrical field, when compared with direct coupling. To achieve a high field strength, a gap cuvette (Fig. 1c) was developed for in vitro experiments due to its short gap width of 2 or $4 \mathrm{~mm}$. Such a cuvette can be used in electroporation for cell suspension and field strengths can be in $\mathrm{kV} / \mathrm{cm}$ range. However, it cannot be used for repeated electrical stimulation because cells need to be suspended. In clinical practice, electrodes could be placed at the defect sites invasively, with a power source nearby (Fig. 1d), or could be placed outside the skin (Fig. 1e).

Cartilage regeneration and OA pose a formidable healthcare challenge. Interestingly, the fact that the application of PES, with appropriate parameters, could enhance regeneration of cartilage and ameliorate OA may open the door to potential clinical applications (Haddad et al., 2007). However, knowledge on the physical and cellular mechanisms of the biological effects of PES is still limited (Schoenbach et al., 2007). To make sense of the multitude and complexity of data within the scientific literature relating to PES and the observed beneficial therapeutic effects, the underlying cellular and molecular mechanisms associated with the application of PES were rigorously delineated, with a focus on chondrocytes, chondrogenic differentiation, and cartilage as models.

\section{Physical models of the effects of electrical stimulation on cells}

Conformational changes to biomolecules induced by electric fields elicit further biological responses. Several physical models for electrical stimulation of living cells, using varying cell parameters and electric 


\begin{tabular}{|c|c|c|c|c|c|c|c|c|c|c|c|c|c|c|c|c|c|}
\hline & 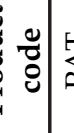 & & $\begin{array}{l}\text { Od } \\
\text { O }\end{array}$ & $\sum_{i=1}^{i}$ & 点 & 战 & $\frac{\tilde{g}}{a}$ & $\begin{array}{l}0 \\
\text { w } \\
0\end{array}$ & 8 & 至 & 灵 & U్ర & 吾 & $\stackrel{\mathrm{N}}{\mathrm{Z}}$ & $\begin{array}{l}x \\
\vdots \\
z\end{array}$ & $\underset{U}{U}$ & $\mathbb{N}$ \\
\hline & $\frac{0}{0}$ & 点 & 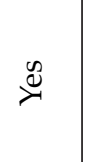 & 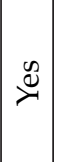 & $\stackrel{\circ}{z}$ & $\stackrel{\infty}{\infty}$ & $\dot{z}$ & ż & z & 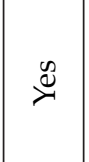 & 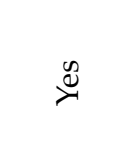 & $\dot{z}$ & $\stackrel{2}{z}$ & $\dot{z}$ & $\dot{z}$ & $\stackrel{\circ}{z}$ & $\dot{z}$ \\
\hline & 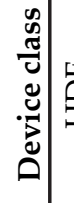 & & $m$ & $\infty$ & $N$ & $\infty$ & $N$ & $N$ & $N$ & $\infty$ & $m$ & $N$ & $N$ & $\infty$ & $N$ & $N$ & $N$ \\
\hline & 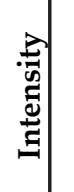 & & & $\mid \begin{array}{l}\vec{z} \\
\dot{\sigma} \\
+\end{array}$ & & & 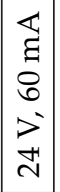 & 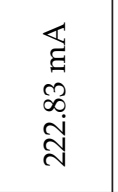 & & & & 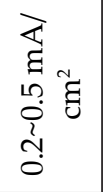 & & $\mid \begin{array}{l}\xi \\
\vdots \\
2 \\
0 \\
0\end{array}$ & & & \\
\hline & 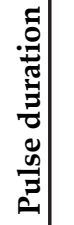 & & $\begin{array}{l}\frac{n}{2} \\
8 \\
\stackrel{+}{1} \\
\text { ते }\end{array}$ & $\left|\begin{array}{l}0 \\
2 \\
8 \\
8 \\
0 \\
0 \\
⿱ 1 \\
7\end{array}\right|$ & & $\begin{array}{l}0 \\
2 \\
8 \\
0 \\
0 \\
8 \\
10 \\
\delta \\
0\end{array}$ & & $\begin{array}{l}\text { ڤ్ } \\
\text { 今े }\end{array}$ & & 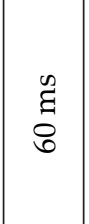 & & 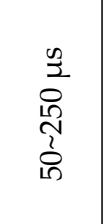 & $\begin{array}{l}0 \\
2 \\
8 \\
0 \\
n\end{array}$ & & 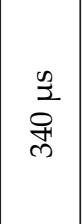 & 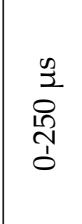 & $\begin{array}{l}\frac{n}{2} \\
8 \\
0\end{array}$ \\
\hline & 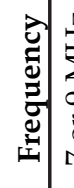 & & & 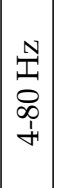 & 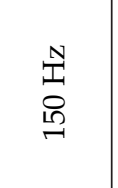 & $\begin{array}{l}\text { ज्ञ } \\
\text { ते }\end{array}$ & 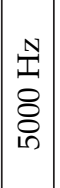 & & & 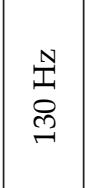 & & 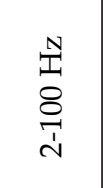 & & 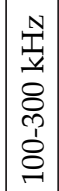 & 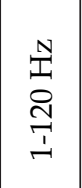 & 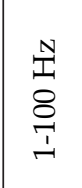 & $\begin{array}{l}\text { N1 } \\
8 \\
8\end{array}$ \\
\hline & : & 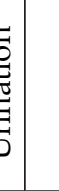 & 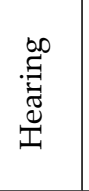 & 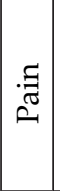 & 窎 & 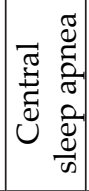 & 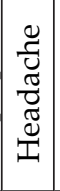 & 苂 & 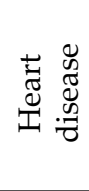 & 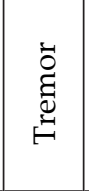 & 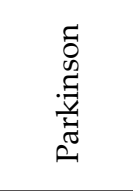 & 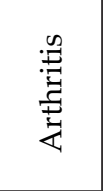 & 苂 & 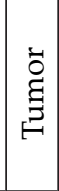 & 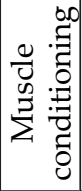 & 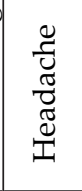 & 寻 \\
\hline & 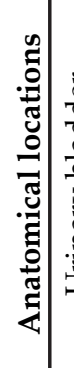 & 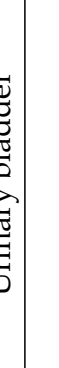 & चี & 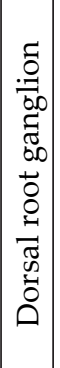 & $\begin{array}{l}\frac{\pi}{n} \\
3 \\
3 \\
3\end{array}$ & 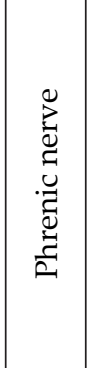 & \begin{tabular}{|l|}
$\vec{u}$ \\
$\ddot{z}$ \\
$\ddot{z}$
\end{tabular} & $\frac{\tilde{y}}{\omega}$ & 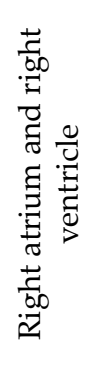 & 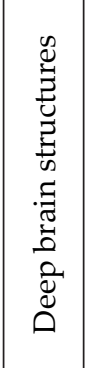 & 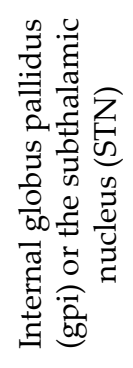 & 节 & 敌 & $\mid \begin{array}{l}\tilde{J} \\
\stackrel{\mathbb{J}}{\mathcal{I}}\end{array}$ & $\frac{\tilde{\Xi}}{\omega}$ & $\begin{array}{l}\tilde{\Xi} \\
\text { के }\end{array}$ & $\frac{\tilde{y}}{\omega}$ \\
\hline & 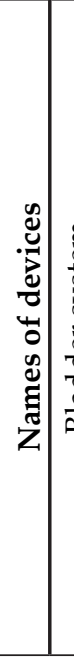 & 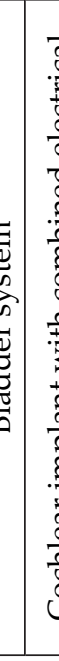 & 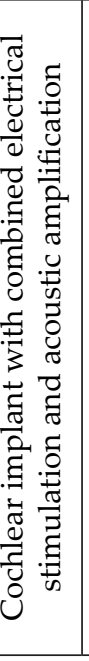 & 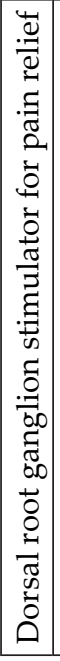 & 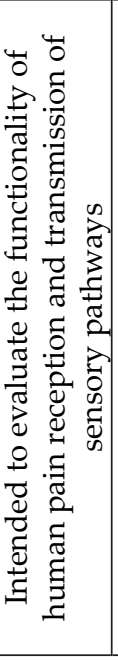 & 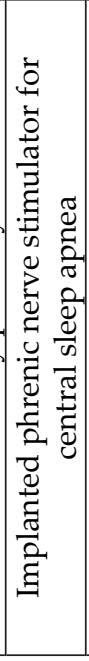 & 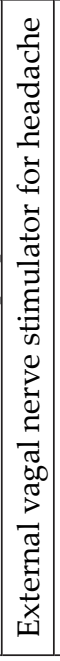 & 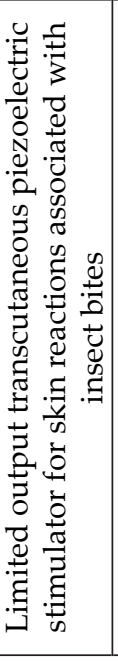 & 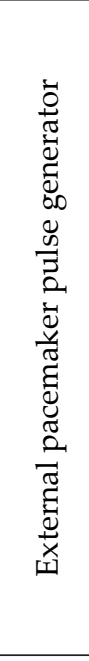 & 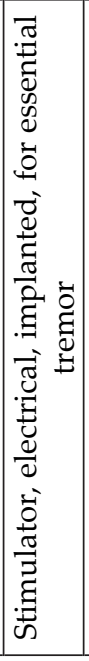 & 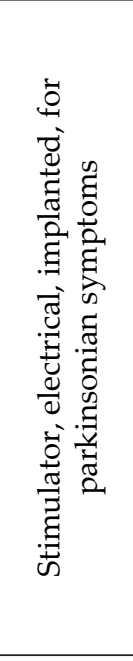 & 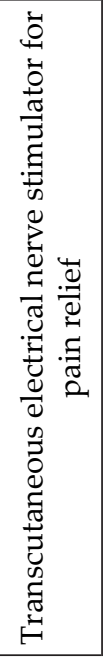 & 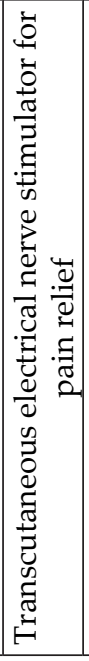 & 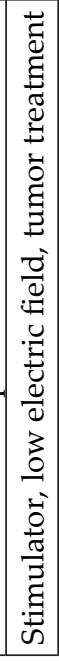 & 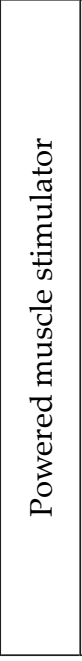 & 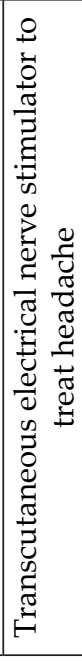 & 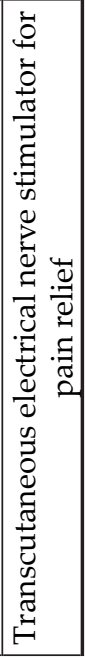 \\
\hline
\end{tabular}


a

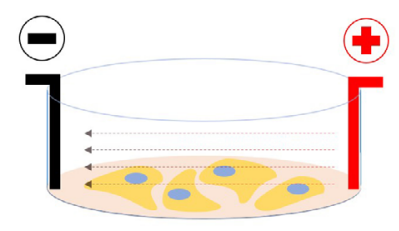

b

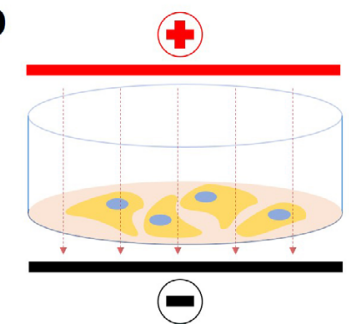

C

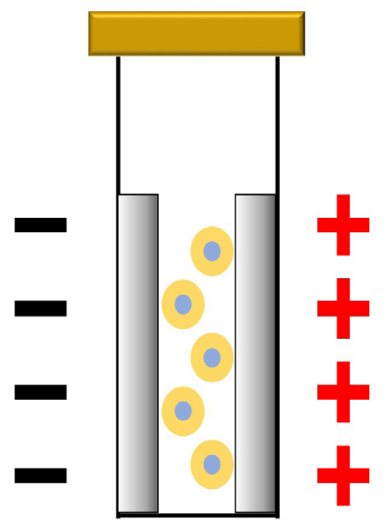

d

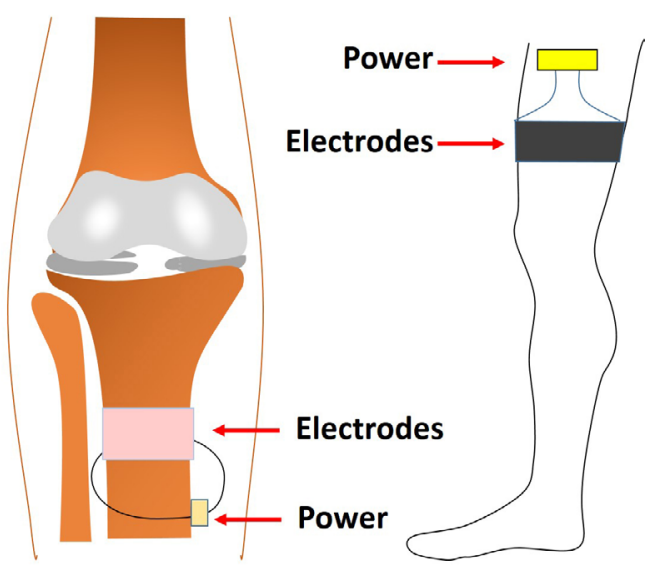

Fig. 1. Device models for PES in vitro and in vivo. (a) Directly applied in a Petri dish in vitro. (b) Capacitive coupling in a Petri dish in vitro. (c) Gap cuvette. (d) Drect current in vivo. (e) Capacitive coupling in vivo.

fields, have been established. Physical models of membrane potential were established as early as 1953 when elliptical cells were exposed to direct electrical currents (Fricke, 1953), while the Schwan equation, based on models of spherical cells, represents one step forward by including extracellular fluid, plasma membrane, and cytoplasmic parameters (Schwan, 1956). The Schwan equation is as follows:

$$
\Delta \psi=1.5 E_{\circ} R \cos \varphi
$$

where $\mathrm{R}$ is the cell radius, $\varphi$ is the angle between the position vector and the applied electric field, $\mathrm{E}_{0}$ is the field strength of the applied electric field, and $\Delta \psi$ is the change in membrane potential.

The multilayer dielectric model of spherical cells lays the foundation for a deeper understanding of the biological effects of PES, which include physical parameters of cell electrical conductivity, relative permittivity, cellular radius, and membrane thickness, as well as cell various organelles and their individual membrane thickness. Based on the multilayer dielectric model of the spherical cell, several conclusions can be drawn (Yao et al., 2009):

1. membrane potentials are positively correlated with the field density of PES;

2. pores in the plasma membrane are formed within a transmembrane voltage range of about $0.5-1 \mathrm{~V}$;

3. the effects of PES with a duration change of $s$ to ps shift from plasma membranes to intracellular structures.

This, in turn, induces complex biological effects, such as activation or inhibition of signaling pathways, phosphorylation of proteins, manipulation of cell phenotypes, while longer durations or higher field strengths will induce apoptosis and necrosis (Weaver et al., 2012) (Fig. 2). The upper boundary of physical parameters is mainly limited by thermal effects and cell death, while the lower boundary is limited by biological effects. Although duration and field density are two key parameters, based on these models and corresponding equations, frequency and timing of electrical stimulation are also critical due to their effect on the action area of PES (Weinberg, 2013). PES with a high frequency $\left(10^{4}-10^{9} \mathrm{~Hz}\right)$ would affect the inner membranes, while PES with a low frequency $\left(<10^{4} \mathrm{~Hz}\right)$ may affect the plasma membrane (Yao et al., 2009).

Field strength, duration, frequency, and time of stimulation are fundamental physical characteristics of PES. Field strength is the intensity of PES and it may range from $\mathrm{mV} / \mathrm{cm}, \mathrm{V} / \mathrm{cm}, \mathrm{kV} / \mathrm{cm}$ to $\mathrm{MV} / \mathrm{cm}$ for different types of application and studies. Duration of PES ranges from ps, ns, $\mu \mathrm{s}, \mathrm{m}$ to $\mathrm{s}$. Long duration plus high voltage would cause thermal effects. Frequency is an important parameter for PES, as PES with a high frequency (above $10 \mathrm{kHz}$ ) could affect intracellular organelles. The time span of stimulation is also important, which may be minutes to hours daily. Repeated stimulation would cause significantly different effects due to cumulative effects. For example, a pulse-number-dependent downregulation of mitochondrial function and cell numbers was observed by Hall et al. (2007) for nsPEFs. $3 \mathrm{~d}$ of PES would not cause significant cell death, while $7 \mathrm{~d}$ of PES would cause significant cell death (Kwon et al., 2016). The formation of pores caused by PES increases due to the increase in pulse number (Yogesh, 2016). On the other hand, PES with a low field strength may require several hours daily to produce significant biological effects (Table 2).

The aforementioned physical model only works well when all individual cells have exactly the same physical properties, as well as disperse uniformly in the cell suspension (Yao et al., 2009). However, distribution of the electric field on individual cells is not even, as cell suspension may not have optimal homogeneity while tissues are absolutely nonhomogenous. The effects of PES are also dependent on cell attachment, as well as changes in cell morphology (Casciola et al., 2017). The distribution of PES is difficult to measure, but could be simulated with commercially available software, such as HFSS 


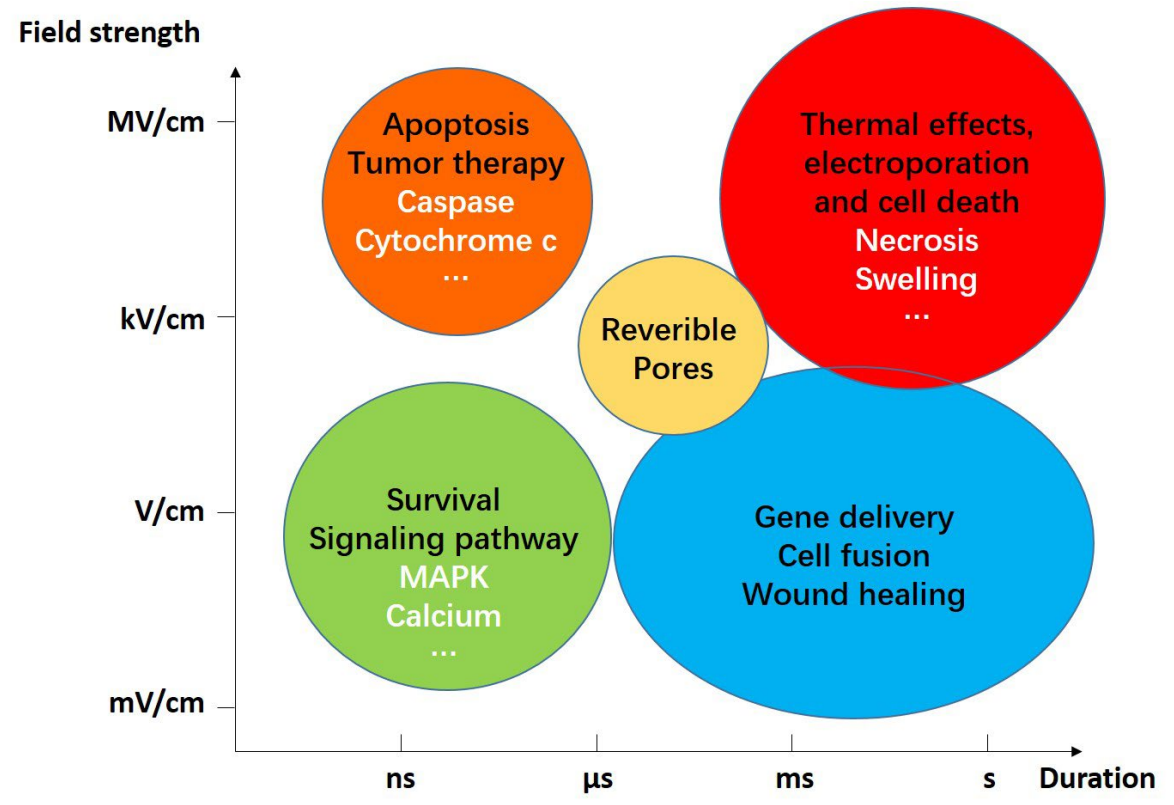

Fig. 2. Biological effects of specific PES parameters. PES can cause different biological effects depending on its parameters. PES with high field strength and long duration can cause thermal effects and cell death. Reversible pore formation can be induced by PES with low field strength and short duration. Irreversible pore formation can be induced by PES with high field strength and long duration.

ANSYS, release 15.0 (ANSYS, Canonsburg, PA, USA) and COMSOL Multi-physics (COMSOL, Burlington, VT, USA) (Buyong et al., 2015; Casciola et al., 2017).

\section{Effects of electrical stimulation on cells and their microenvironment}

The effects of PES on different cellular components have been explored extensively, including VSDs, plasma membrane, intracellular components, and signaling pathways, which are often interwoven. PES induces conformational changes of voltagesensitive proteins, pore formation in the membrane, and calcium influx within seconds of its application, which, in turn, leads to activation of signaling pathways, cell migration, and cell death within minutes or hours.

\section{VSDs}

Conformational changes of proteins are early stage key biological effects of PES which are still unexplored. VSDs, key components of voltagegated channels, usually are comprised of four transmembrane helices (S1-S4) with a pore domain (helices S5 and S6). The S4 segment of voltage-gated channels with the motif [RK]-X(2)-R-X(2)-R-X(2)[RK] is sensitive to electric fields (Murata et al., 2005). The basic residues of S4 segment are rapidly changed from hyperpolarized potentials, with an internally connected aqueous crevice, to depolarized potentials, with an externally connected aqueous crevice (Zhang et al., 2012). Electrical stimulation induces high levels of intracellular $\mathrm{Na}^{+}$ions by the activation of $\mathrm{Na} / \mathrm{K}$ ATPase, which is responsible for at least $35 \%$ of the voltage-induced pores in the plasma membrane (Teissie and Tsong, 1980). However, electrical stimulation with a high intensity induces a negative-shift of channel open-threshold and reduces conductance of $\mathrm{K}^{+}$channels, which may be due to conformational changes causing supraphysiological voltage in the membrane proteins of channel-gating systems (Chen, 2004). Furthermore, PES could denature voltage-sensitive membrane proteins with charged groups in some of their component amino acids which are sensitive to the plasma membrane potential (Chen, 2005). This may be due to breakage of chemical bonds between amino acids in the voltage-dependent membrane proteins, thus reducing their ability to open potassium ion channels simultaneously. From another point of view, nsPEFs inhibit voltage-gated $\mathrm{Ca}^{2+}$ and $\mathrm{Na}^{+}$channels with reduction of the transmembrane ion gradient due to an increase in non-inactivating "leak" current (Nesin et al., 2012). Channel subtypes should also be considered, as voltage-gated potassium channels respond to electrical stimulation variably, depending on channel kinetics (Cameron et al., 2017). Reduction in the opening process of ion channels is less reversible in comparison to the process of inducing reversible pores by electroporation, which reclose within $\mu$ s or ms. This mechanism is clinically significant as it helps illustrate how injuries caused by electric shock often show no signs of tissue damage but still result in malfunction (Chen, 2005). The presence of naturally occurring proteins with magnetic response hint at a possibility that there may be more proteins that have intrinsic capacity to respond to electrical stimulation (Qin et al., 2016).

\section{Membrane}

PES with varying durations has selective effects on either the plasma membrane or intracellular membranes. In terms of duration of pulses, PES is classified into several groups, including $\mu \mathrm{s}, \mathrm{sub}-\mu \mathrm{s}$, ns, and ps (Yao et al., 2009). Living cells respond to PES variably since they are conceptualized as a combination of capacitors and resistors with 
Table 2. Effects of PES on chondrocytes.

\begin{tabular}{|c|c|c|c|}
\hline Model & Electric parameter & Results & References \\
\hline $\begin{array}{l}\text { Fetal bovine } \\
\text { articular } \\
\text { chondrocytes }\end{array}$ & $\begin{array}{c}\text { Frequency: } 60 \mathrm{~Hz} \\
\text { Time: } 0.5 \mathrm{~h} \\
\text { Intensity: } 20 \mathrm{mV} / \mathrm{cm}\end{array}$ & $\begin{array}{c}C O L I I \text { and } A G G \uparrow \\
\text { PG and collagen content } \uparrow\end{array}$ & $\begin{array}{l}\text { (Wang et al., } \\
\text { 2004) }\end{array}$ \\
\hline $\begin{array}{c}\text { Adult bovine } \\
\text { articular } \\
\text { chondrocytes }\end{array}$ & $\begin{array}{l}\text { Frequency: } 60 \mathrm{kHz} \\
\text { Intensity: } 20 \mathrm{mV} / \mathrm{cm} \\
\text { Time: } 4,6 \text { or } 22 \mathrm{~h} \\
\end{array}$ & COLII and $A G G \uparrow$ & (Xu et al., 2009) \\
\hline $\begin{array}{c}\text { Pig } \\
\text { chondrocytes }\end{array}$ & $\begin{array}{c}\text { Frequency: } 1 \mathrm{~Hz} \\
\text { Pulse: 5; pulse duration: } 100 \mathrm{~ns} \\
\text { Intensity: } 10 \mathrm{kV} / \mathrm{cm} \text { or } 20 \mathrm{kV} / \mathrm{cm}\end{array}$ & $\begin{array}{c}\text { Dedifferentiation } \\
C O L I \uparrow, A G G \downarrow, C O L I I \downarrow \text {, and } \\
\text { SOX } 9 \downarrow\end{array}$ & $\begin{array}{l}\text { (Zhang et al., } \\
\text { 2014) }\end{array}$ \\
\hline $\begin{array}{l}\text { Human } \\
\text { chondrocytes }\end{array}$ & $\begin{array}{c}\text { Frequency: } 4150 \mathrm{~Hz} \\
\text { Time: } 30 \mathrm{~min} \\
\text { Intensity: } 0.1 \text { to } 10 \mathrm{mV} / \mathrm{cm} \\
\text { Pulse duration: } 10 \mathrm{~ms}\end{array}$ & Proliferation $\uparrow$ & $\begin{array}{l}\text { (Fitzsimmons et } \\
\text { al., 2008) }\end{array}$ \\
\hline $\begin{array}{c}\text { Human } \\
\text { chondrocytes }\end{array}$ & $\begin{array}{l}\text { Frequency: } 10 \mathrm{~Hz} \\
\text { Current: } 10 \mu \mathrm{A} \\
\text { Time: } 3 \text { or } 6 \mathrm{~h} \\
\end{array}$ & $\begin{array}{l}\text { Chondrocyte adhesion } \uparrow \\
\text { Long-term cell densities } \uparrow\end{array}$ & $\begin{array}{l}\text { (Khang et al., } \\
\text { 2008) }\end{array}$ \\
\hline $\begin{array}{l}\text { Bovine articular } \\
\text { chondrocytes }\end{array}$ & $\begin{array}{c}\text { Frequency: } 60 \mathrm{kHz} \\
\text { Intensity: } 0-45 \mathrm{mV} / \mathrm{cm} \\
\text { Time: } 24 \mathrm{~h} \\
\end{array}$ & $\begin{array}{c}15-30 \mathrm{mV} / \mathrm{cm} \text { : proliferation } \uparrow \\
45 \mathrm{mV} / \mathrm{cm} \text { : proliferation } \downarrow \text { and } \\
\text { proteoglycan } \uparrow\end{array}$ & $\begin{array}{c}\text { (Armstrong et } \\
\text { al., 1988) }\end{array}$ \\
\hline
\end{tabular}

multilayer dielectric models (Schoenbach et al., 2007; Yao et al., 2009). Charging time constant is the time required to charge a plasma membrane (Deng et al., 2003). The equations for charging time $(\tau)$ of the outer membrane and the inner membrane are as follows (Yao et al., 2009). According to the multilayer dielectric model of a spherical cell, the constant $\tau_{\text {cell }}$ of the outer membrane (plasma membrane) can be expressed as

$$
\tau_{\text {cell }}=\left(\frac{1}{2 \gamma_{o}}+\frac{1}{\gamma_{c}}\right) \frac{\varepsilon_{i} \varepsilon_{m}}{d_{m}} R_{c}
$$

The constant $\tau_{\text {nuc }}$ of the inner membrane (organelle membranes) can be expressed as

$$
\tau_{n u c}=\left(\frac{1}{2 \gamma_{c}}+\frac{1}{\gamma_{n c}}\right) \frac{\varepsilon_{i} \varepsilon_{n m}}{d_{n}} R_{n}
$$

$\gamma_{\mathrm{o}^{\prime}} \gamma_{\mathrm{c}}$ and $\gamma_{\mathrm{nc}}$ are the conductivities of extracellular medium, cytoplasm and organelle cytoplasm, respectively. $\varepsilon_{\mathrm{i}^{\prime}} \varepsilon_{\mathrm{m}}$ and $\varepsilon_{\mathrm{nm}}$ are the permittivities of vacuum, plasma membrane and organelle membrane, respectively. $d_{m}$ and $d_{n}$ denotes the thicknesses of the cell and organelle membranes, respectively. $R_{c}$ and $R_{n}$ are the radii of the cell and organelle, respectively. According to the above equations, the transmembrane potential of the membrane is as follows. At the end of the pulse, the outer membrane transmembrane potential is

$$
V_{m}=1.5 R_{c} E\left(1-e^{-\frac{\tau}{\tau_{\text {cell }}}}\right) \cos \theta
$$

and the inner membrane transmembrane potential is

$$
V_{n}=\frac{1.5 \tau_{\text {cell }} R_{n} E}{\tau_{\text {cell }}-\tau_{\text {nuc }}}\left(e^{-\frac{\tau}{\tau_{\text {cell }}}}-e^{-\frac{\tau}{\tau_{n u c}}}\right) \cos \theta
$$

$E$ is the field intensity of the external electric field. $\theta$ is the polar angle measured with respect to the direction of the field. $\tau$ is the duration of the electric fields. Voltage of the plasma and organelle membranes are affected by the relationship of the size of $\tau, \tau_{\text {cell }}$ and $\tau_{\text {nuc }} \cdot \tau_{\text {cell }}$ is in the range of hundreds of ns, while $\tau_{\text {nuc }}$ is in the range of about tens of ns. $\tau$ may be different for different cells, because different cells in different environment have different physiological parameters. If $\tau$ is much larger than $\tau_{\text {cell }}$ then the outer membrane can be fully charged by electric fields. If $\tau$ is much smaller than $\tau_{\text {cell }}$ then the outer membrane is poorly charged by electric fields. That is the same for the inner membrane. $\tau_{\text {cell }}$ is in the range of hundreds of ns for most cells and $\tau_{\text {nuc }}$ is in the range of tens of ns for most cells.

Based on the charge time of the plasma membrane, PES with durations of $\mu$ s or longer, mainly exert effects on the cell outer membrane, while PES with a sub- $\mu$ d duration exert effects on both the inner and outer membrane with a sufficient PES intensity (at the $\mathrm{kV} / \mathrm{cm}$ level) (Yao et al., 2009). nsPEFs with intensities up to $300 \mathrm{kV} / \mathrm{cm}$ have better penetrative capacity and mainly affect the inner cell membrane (Chopinet and Rols, 2015; Schoenbach, 2018). Theoretically, electrical stimulation with even shorter durations of ps could be endowed with even higher voltages. Ps-pulsed electrical stimulation with an intensity lower than $1 \mathrm{kV} / \mathrm{cm}$ hardly affects the plasma membrane (Yao et al., 2009). The intensity of electric fields is limited to less than $1 \mathrm{kV} / \mathrm{cm}$, while the duration ranges from $\mu$ s to ms (Zimmermann, 1986). Relatively short durations and high field strengths (hundreds kV/ $\mathrm{cm})$ can potentially affect the intracellular membrane while restricting total energy and narrowing down the previously broad biological effects. In any case, precise control of PES is essential for various potential clinical applications and more attention should be paid to nsPEFs.

PES has the unique ability to induce reversible pore formation in plasma membranes within seconds, 
including the outer plasma membrane, as well as intracellular organelles, such as mitochondria, endoplasmic reticulum, and nuclear membranes. PES induces changes in membranes immediately. Changes are reversible under PES with a low voltage and short duration, while irreversible under PES with a high voltage and long duration (Pakhomov et al., 2015). Pores that form on plasma membranes are temporary and reversible when an electric field strength of about $0.1-20 \mathrm{kV} / \mathrm{cm}$ and pulse durations of $10 \mathrm{~ns}-10 \mathrm{~ms}$ are applied (Kirawanich et al., 2010; Kotnik et al., 2015). These temporary pores have been widely used in biomedical applications, including delivery of biomolecules, such as DNA, RNA, and proteins - commonly referred to as electroporation or electrofusion (Cemazar et al., 2013; Schoellhammer et al., 2014) - as well as drugs (Okino and Mohri, 1987). The voltage applied in electroporation can range between $200 \mathrm{~V}$ and $350 \mathrm{~V}$, with $260 \mathrm{~V}$ being the most widely used (Nature Methods, 2006). The electrofusion technique is based on electroporation at $300 \mathrm{~V}$ pulse of the plasma membrane and is mediated by PEG (Hui and Stenger, 1993; Yu et al., 2008). The effects of electrofusion on different cell types, cell sizes, and intensity of electric field have been studied. Traditionally, the duration of electric fields used for electrofusion range between 10 and $100 \mu \mathrm{s}$ (Jordan et al., 2013; Rems et al., 2013), while nsPEFs increase efficiency of cell electrofusion through electroporation of the contact areas between cells (Rems et al., 2014). Size of pores created by nsPEFs on the membrane are smaller than that caused by PES with longer durations (Vasilkoski et al., 2006).

\section{Intracellular components and organelles}

PES affects intracellular components and organelles, such as the cytoskeleton. PES increases speed of cell migration of both inner and outer meniscus cells (Yuan et al., 2014) and ROS levels in both extracellular (electrochemical) and intracellular compartments (Pakhomova et al., 2012). PES [10 ns, high voltages $(>150 \mathrm{kV} / \mathrm{cm})]$ disrupts pre-messenger RNAs by inducing nuclear speckles of snRNPs (Chen et al., 2007). PES with a low field strength $(2.5 \mathrm{~V} / \mathrm{cm})$ accelerates cell migration within hours (Hayashi et al., 2016). PES with a duration of ns can induce disassembly of actin structures and cell swelling resulting from cell permeabilization (Pakhomov et al., 2014). Whereas, PES effects on ribosomes remain unexplored.

PES can induce apoptosis through dysfunctioning mitochondria. PES with a high field strength $(\mathrm{kV} /$ $\mathrm{cm}$ ) and a short duration of ns range decreases mitochondria membrane potential (Beebe et al., 2012). The loss of mitochondria membrane potential may be a consequence of increased inner mitochondrial membrane permeability (Batista Napotnik et al., 2012). PES with a duration of ps can induce the release of cytochrome $\mathrm{C}$ from mitochondria, with activation of caspase 3 and 9, resulting in apoptosis (Hua et al., 2012).
PES also affects epigenetics through acetylation, histone modifications, alteration of the structural organization of chromatin, demethylation, as well as affecting RNA. PES downregulates histone deacetylase activities in HL-1 cells, with a significant reduction in Cx43 expression and cellcell communication (Meraviglia et al., 2015). PES can also reversibly downregulate the activity of histone 1 kinase in pig oocytes (Leal and Liu, 1998). PES can prevent the tumorigenic transition of embryonic stem cells through downregulation of phospho-H3 and Ki67 immuno-reactivity (Yamada et al., 2007). PES promotes global DNA demethylation and downregulates DNMT1 expression (unpublished data).

\section{Signaling pathways}

PES exerts effects on cells through activation or inhibition of various signaling pathways (Liu and Song, 2014). PES activates protein kinase C signaling pathway by inducing PIP2 hydrolysis (Tolstykh et al., 2013). PES inhibits VEGF signaling pathway via downregulation of VEGF and PD-ECGF, thereby disrupting pro-angiogenic and anti-angiogenic balance, which may consequently inhibit cancer development and suppress tumor blood vessel growth (Chen et al., 2007). PES activates MAPK signaling pathway. PES not only upregulates phosphorylation of ERK and p38 (Zhao et al., 2006), but can also activate JNK, another member of the MAPK family, with fast increased phosphorylation level within minutes, which then decreases within $1 \mathrm{~h}$ (Morotomi-Yano et al., 2011a; 2011b). As the signaling pathways activated by PES may become inactivated within minutes or hours, the effect caused by PES may last for minutes, hours, or days. PESpreconditioning promotes cartilage regeneration within weeks through enhancing differentiation of MSCs (Ning et al., 2019). This is the consequence of the biological effects initiated by PES during the early stage after stimulation. Meanwhile, phosphorylation of MAPK caused by PES is reversible (Morotomi-Yano et al., 2011a). PES can also induce dedifferentiation of chondrocytes through activation of Wnt/ $\beta$-catenin signaling pathway (Zhang et al., 2014). Activation of $\beta$-catenin signaling pathway enhances NEUROG2 expression in brain injury after PES treatment (Matsumoto et al., 2013) (Fig. 3).

PES exerts effects on calcium-related signaling pathways through the release of $\mathrm{Ca}^{2+}$ ions from endoplasmic reticulum compartments (Semenov et al., 2013; Vernier et al., 2003). PES with high field strength can induce calcium release within seconds (Zhang et al., 2014). PES has been reported to induce release of $\mathrm{Ca}^{2+}$ leading to an increase in cytoskeletal CaM levels (Brighton et al., 2001). PES can also induce calcium influx from the external medium (Bourguignon et al., 1989). PES enhances proliferation of cardiac fibroblast and myocardial fibrosis through activation of the CaN-NFAT pathway, regulated by $\mathrm{Ca}^{2+} / \mathrm{CaM}$ (Chen et al., 2012). PES increases synthesis 
of NO and production of cGMP through calcium/ CaM and inhibits $\mathrm{Ca}^{2+} / \mathrm{CaM}$, thereby blocking these effects (Fitzsimmons et al., 2008).

PES can also regulate the process of apoptosis and its associated biochemical markers. PES activates caspase-dependent signaling pathways in apoptosis, with the activation of caspase-12, -9 , and -3 , leading to release of cytochrome c, upregulation of Bax and downregulation of Bcl-2 in HeLa cells (Chen et al., 2013).

\section{Physiological microenvironment}

PES can alter blood flow, temperature, and $\mathrm{pH}$ of tissues. Blood flow is significantly increased following application of electrical stimulation in wound healing (Ud-Din et al., 2015). Increased blood flow following increasing capillary density is observed when the transcutaneous oxygen partial pressure is increased by $82.4 \%$ during treatment of CVI (Jünger et al., 1997). Thermal effects are integral in traditional PES, but on the other hand, thermal effects are dependent on tissue properties as well as stimulation parameters (i.e., frequency, pulse duration, field strength) (Schoenbach et al., 2004). Electrical stimulation increases temperature around the electrodes in the visual prosthesis system (Çelik and Karagöz, 2014). Temperature is increased around the electrodes (both anode and cathode) and the $\mathrm{pH}$ value varied from 3 (near the anode) to 12 (near the cathode) in the electrode array for local control of solid tumors (Soba et al., 2018). Low-voltage electrical stimulation can promote muscle tenderness and accelerate glycolysis, with a significant fall in $\mathrm{pH}$ during the first $6 \mathrm{~h}$ post mortem (Polidori et al., 1999).

PES has been reported to cause deleterious effects on cells, including cell death and cell fragmentation (Yang et al., 2018). PES with high field strength and long duration can result in thermal effects due to Joule heating (Yarmush et al., 2014), with consequent cell death, as proteins denature when the temperature reaches about $43-45^{\circ} \mathrm{C}$. Also, nsPESs with high field strength lead to cell death within minutes, which is mainly due to cell fragmentation (Ning et al., 2019). PES with high field strength and long duration can also induce cell death, following both necrotic and apoptotic ways (Pakhomova et al., 2013).

\section{Effects of PES on chondrocytes, mesenchymal stem cells, cartilage explants, and OA}

PES promotes cartilage regeneration and ameliorate OA through modulation of extracellular matrix and various biological factors, such as BMPs, TGF- $\beta$, and IGF2, which in turn induce anti-inflammatory and anabolic effects to improve articular cartilage regeneration together with amelioration of inflammation (Haddad et al., 2007; Massari et al., 2007). Cell-based repair strategies induce cartilage regeneration (Johnstone et al., 2013). Chondrocytes and MSCs (or their chondrogenic progenies) are important cell sources (de Vries-van Melle et al., 2014; Estes et al., 2010; Guilak et al., 2010). Both ADSCs and BMSCs have demonstrated their unique responses to growth-factor-induced chondrogenic differentiation, respectively to TGF- $\beta 3$ and BMP6 (Diekman et al., 2009). However, there are obstacles to using primary chondrocytes for cell culture applications, including limited cell numbers and dedifferentiated phenotypes during in vitro expansion (Chung and Burdick, 2008). Challenges faced in culturing bone-marrow-derived MSCs or ADSCs in vitro include low efficiency of chondrogenic differentiation and heterogeneous phenotypes (Perdisa et al., 2015; Somoza et al., 2014), while proper application of PES could potentially overcome these obstacles.

\section{Chondrocytes}

PES can induce varied or even opposite effects on chondrocytes, including increased proliferation and increased or decreased differentiation (represented as expression of CollI or ratio of CollI/Coll and GAG production). PES for $24 \mathrm{~h}$ at $15-30 \mathrm{mV} / \mathrm{cm}$ increases proliferation of primary chondrocytes harvested

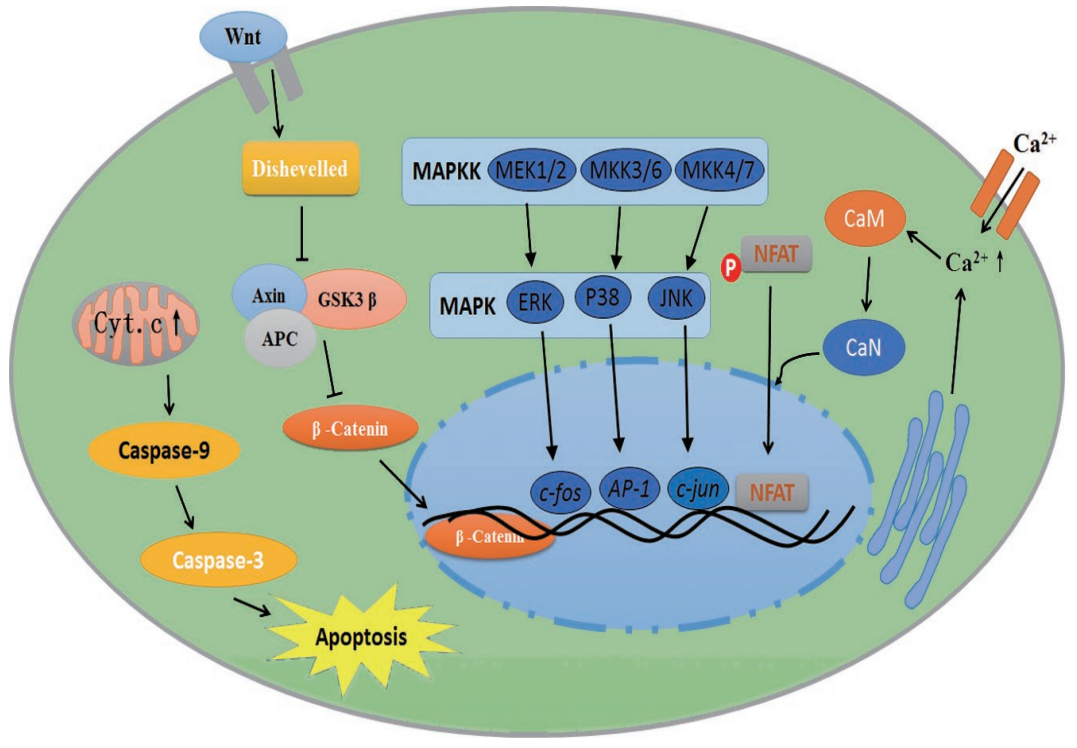

Fig. 3. Signalling pathways activated by PES for a generic cell. MAPK and its downstream signalling pathways are activated by PES. Calcium influx is induced by PES. Cell death could be induced by PES through the caspase signalling pathway. Wnt//3-catenin signalling pathway could be activated by PES. 
Table 3. Effects of PES on cartilage explants.

\begin{tabular}{|c|c|c|c|c|}
\hline Model & Other factors & Electrical parameters & Results & References \\
\hline $\begin{array}{c}\text { Calf cartilage } \\
\text { disks }\end{array}$ & & $\begin{array}{c}\text { Frequency: } 1,10,100,10^{3}, \\
\text { and } 10^{4} \mathrm{~Hz} \\
\text { Intensity: } 10-30 \mathrm{~mA} / \mathrm{cm}^{2}\end{array}$ & Protein synthesis $\uparrow$ & $\begin{array}{c}\text { (Macginitie et al., } \\
\text { 1994) }\end{array}$ \\
\hline $\begin{array}{l}\text { Bovine articular } \\
\text { cartilage explants }\end{array}$ & & $\begin{array}{c}\text { Frequency: } 60 \mathrm{~Hz} \\
\text { Intensity: } 20 \mathrm{mV} / \mathrm{cm} \\
\text { Time: } 1 \mathrm{~h} \text { on and } 5 \mathrm{~h} \text { off, } \\
4 \text { times/d for } 3 \mathrm{~d}\end{array}$ & $\begin{array}{c}\text { Production of proteoglycan } \\
\text { and collagen } \uparrow \\
A G G \text { and COLII } \uparrow\end{array}$ & $\begin{array}{c}\text { (Brighton et al., } \\
\text { 2006) }\end{array}$ \\
\hline $\begin{array}{c}\text { Human } \\
\text { osteoarthritic } \\
\text { cartilage explants }\end{array}$ & $\begin{array}{l}\text { With or without } \\
\qquad 1 \mathrm{~L}-1 \beta\end{array}$ & $\begin{array}{c}\text { Frequency: } 60 \mathrm{kHz} \\
\text { Intensity: } 20 \mathrm{mV} / \mathrm{cm} \\
\text { Time: } 1 \mathrm{~h} \text { on and } 5 \mathrm{~h} \text { off, } \\
4 \text { times/d for } 3 \mathrm{~d}\end{array}$ & $\begin{array}{c}\text { With IL-1 } \beta \text { : production of } \\
\text { proteoglycan and collagen } \uparrow \\
\text { AGG and COLII } \uparrow\end{array}$ & $\begin{array}{c}\text { (Brighton et al., } \\
\text { 2008) }\end{array}$ \\
\hline
\end{tabular}

from growth plate cartilage, with upregulated $\left[{ }^{3} \mathrm{H}\right]$ thymidine uptake, and enhances proteoglycan deposition, with upregulated [ $\left.{ }^{35} \mathrm{~S}\right]$ sulfate uptake, while PES for $24 \mathrm{~h}$ at $45 \mathrm{mV} / \mathrm{cm}$ inhibits proliferation and enhances proteoglycan deposition (Armstrong et al., 1988). PES (0.5 h, $20 \mathrm{mV} / \mathrm{cm}, 60 \mathrm{~Hz})$ can increase COLII and AGG expression in fetal bovine chondrocytes in a micromass culture system (Wang et al., 2004). PES (4, 6 or $22 \mathrm{~h}, 60 \mathrm{kHz}, 20 \mathrm{mV} / \mathrm{cm})$ induces up-regulation of both COLII and $A G G$ expression levels through extracellular $\mathrm{Ca}^{2+}$ influx through voltage-gated calcium channels rather than intracellular $\mathrm{Ca}^{2+}$ repositories (Xu et al., 2009). PES (3 or $6 \mathrm{~h}, 10 \mathrm{~Hz}, 10 \mu \mathrm{A}$ ) enhances chondrocyte adhesion and long-term cell densities for up to $2 \mathrm{~d}$ (Khang et al., 2008). On the other hand, nsPEFs (5 pulses, $1 \mathrm{~Hz}$, $100 \mathrm{~ns}$ at 10 or $20 \mathrm{kV} / \mathrm{cm}$ ) decreases gene expression levels of COLII, AGG and SOX9 through activation of Wnt/ $\beta$-catenin signaling pathway and intracellular calcium ion efflux (Zhang et al., 2014) (Table 2).

This obvious inconsistency could be attributed to either varying parameters of PES or cell types with ever-changing intra- and inter-cellular structures. Generally, PES with low electric field strength and long duration promotes proliferation with effects mainly on calcium homeostasis, cell skeleton, or membrane, while PES with high electric field strength affects intracellular structures or more specific targets.

\section{Chondrogenic differentiation of MSCs}

PES has been optimized to promote chondrogenic differentiation of MSCs (Table 4). Piezoelectric scaffolds, exhibiting low voltage output, enhance chondrogenic differentiation of MSCs with upregulation of intense proteoglycan staining and COLII, while piezoelectric scaffolds with high voltage output enhance osteogenic differentiation (Damaraju et al., 2017). This emphasizes the importance of PES parameters in chondrogenic differentiation. PES (20 min daily for $7 \mathrm{~d}, 20 \mathrm{mV} / \mathrm{cm}, 60 \mathrm{KHz}$ ), with or without TGF- $\beta 3$, promotes chondrogenic differentiation, with enhanced COLII and SOX9 expression levels (Esfandiari et al., 2014). PES (20 $\mathrm{min}, 1 \mathrm{kHz}, 20 \mathrm{mV} / \mathrm{cm}$ ) leads to chondrogenic differentiation of ADSCs (Mardani et al., 2016). TGF- $\beta$, BMPs and other signaling pathways have been implicated in PES treatment. PES $(1,5$ or $25 \mathrm{~V} /$ $\mathrm{cm}, 5 \mathrm{~Hz}$ ) promotes chondrogenic differentiation via upregulated SOX9, COLII, and AGG, with TGF- $\beta$ signaling, BMP signaling and extracellular ATP

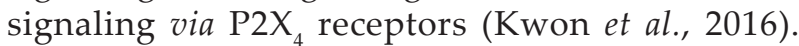
Electrical stimulation induces calcium oscillations through modulation of VOCCs, which are implicated in chondrogenesis (Uzieliene et al., 2018). PES (nsscale with high intensity) enhances chondrogenic differentiation of MSCs with significantly upregulated expression levels of SOX9,COLII, and AGG, together with down-regulated expression of COLX through activation of c-Jun and Stat3 signaling pathways (Ning et al., 2019). ns-PESs promote chondrogenic differentiation of MSCs through activation of MAPK signaling pathways (Morotomi-Yano et al., 2011a).

PES can promote chondrogenic differentiation through upregulation of related growth factors. PES (50 and $100 \mathrm{mV} / \mathrm{mm}$ ) also increases FGF2 secretion and upregulates phosphorylation levels of Smad2 and Smad3 in fibroblasts (Wang et al., 2017). PES (50 mV/ $\mathrm{mm}$ ) upregulates the secretion of FGF1 and FGF2 in fibroblasts (Rouabhia et al., 2013). PES (5 V, $0.1 \mathrm{ms,}$ $10 \mathrm{~min}$ ) together with a heat shock can activate insulin signaling through phosphorylation of IRS (Morino et al., 2008). However, disruption of the secondary structure of insulin is observed at higher electric field strengths (above $0.25 \mathrm{~V} / \mathrm{nm}$ ) within $1 \mu$ s (Wang et al., 2014) and the binding capacity of insulin to receptors is significantly reduced by long PES duration (0.7 V/m, $50 \mathrm{~Hz}, 20 \mathrm{~min}$ ) (Li et al., 2005). So, whether insulin is involved in chondrogenic differentiation of MSCs by PES remains to be explored. Perhaps low intensity PES can activate insulin signaling pathway to promote chondrogenic differentiation while high intensity PES can not.

\section{Cartilage explants and $\mathrm{OA}$}

PES can increase matrix production and reduce matrix destruction in cartilage explants. PES $(60 \mathrm{kHz}$, $20 \mathrm{mV} / \mathrm{cm}$ ) increases production of proteoglycan and collagen in the absence or presence of IL-1 $\beta$, while dramatically inhibiting expression of matrix 
Table 4. Effects of PES on the chondrogenic differentiation of MSCs.

\begin{tabular}{|c|c|c|c|}
\hline Model & Electrical parameter & Results & References \\
\hline $\begin{array}{c}\text { Piezoelectric scaffolds } \\
\text { Human MSCs }\end{array}$ & $20 \mathrm{mV} / \mathrm{mm}$ & GAG and COLII $\uparrow$ & (Damaraju et al., 2017) \\
\hline Human ADSCs & $\begin{array}{c}\text { Frequency: } 60 \mathrm{KHz} \\
\text { Intensity: } 20 \mathrm{mV} / \mathrm{cm} \\
\text { Time: } 20 \text { min daily for } 7 \mathrm{~d}\end{array}$ & COLII and SOX9 $\uparrow$ & (Esfandiari et al., 2014) \\
\hline ADSCs & $\begin{array}{c}\text { Frequency: } 1 \mathrm{kHz} \\
\text { Intensity: } 20 \mathrm{mv} / \mathrm{cm} \\
\text { Time: } 20 \mathrm{~min}\end{array}$ & COLII and SOX9 $\uparrow$ & (Mardani et al., 2016) \\
\hline Mouse MSCs & $\begin{array}{c}\text { Frequency: } 5 \mathrm{~Hz} \\
\text { Intensity: } 1,5 \text { or } 25 \mathrm{~V} / \mathrm{cm}\end{array}$ & $\begin{array}{c}\text { COLII and SOX9 } \uparrow \\
\text { COLI } \downarrow\end{array}$ & (Kwon et al., 2016) \\
\hline Pig MSCs & $\begin{array}{c}\text { Frequency: } 1 \mathrm{~Hz} \\
\text { Intensity: } 10 \mathrm{kV} / \mathrm{cm}, 20 \mathrm{kV} / \mathrm{cm} \\
\text { Duration: } 10 \mathrm{~ns}, 100 \mathrm{~ns}\end{array}$ & COLII and SOX9 $\uparrow$ & (Ning et al., 2019) \\
\hline
\end{tabular}

metalloproteinase in full-thickness osteoarthritic adult human articular cartilage explants (Brighton et al., 2008). Brighton et al. (2006) observed that PES $(60 \mathrm{kHz}, 20 \mathrm{mV} / \mathrm{cm})$ increases collagen production and expression levels of COLII and AGG within adult bovine articular cartilage explants (Table 3).

PES used for neuromuscular stimulation increased muscle thickness and pennation angle in 45 women (age 66-75 years) with knee OA and it resulted in a significant increase in functional capacity, as measured by the 6 min walk test and Timed Up and Go Test (Melo Mde et al., 2015). PES resulted in high global effectiveness of OA treatment in two patients (Fary et al., 2009). However, the third patient exhibited no change, emphasizing the importance of heterogeneity. PES resulted in a significant downregulation of various OA symptoms in hands, with respect to pain, swelling, grip strength, and pinch force (Holt et al., 2018).

The effects of PES on OA pain relief remains to be explored. Neuromuscular electrical stimulation reduces pain (de Oliveira Melo et al., 2016). PES can alleviate pain in OA. PES (at least $6 \mathrm{~h} / \mathrm{d}$ for 3 months) significantly reduced pain in patients with knee $O A$ in clinical trials (Garland et al., 2007). Although PES could improve physical functions in subjects with knee OA, it may not reduce pain. PES attenuated knee OA symptoms in a dose-response manner after $750 \mathrm{~h}$ in a clinical trial with 288 patients who had failed nonsurgical therapy (Farr et al., 2006). However, contrary results were also reported in which PES could not provide symptomatic relief for OA (Fary et al., 2008; 2011). This difference may be due to limitations of the sample size and heterogeneity, such as age or BMI. Maybe the type of electrical stimulation could change the effects of PES on pain relief. Among electrical stimulation therapy, from h-TENS, l-TENS, NMES, IFC, PES to NIN, IFC seems to be the best treatment modality in terms of effectiveness, as compared with PES and other electrical stimulation modalities (Zeng et al., 2015). Amplitude-modulated frequency generated by IFC can permeate more deeply, which could improve pain relief, as the main analgesic component of IFC (Johnson et al., 2003). Meanwhile, con mechanisms in the observed effects of electrical stimulation on OA need to be further explored to optimize the treatment, such as thermal effects, cell migration, blood flow etc.. Perhaps PES with a low frequency $(\leq 100 \mathrm{~Hz})$ is able to improve physical function but not pain intensity (Negm et al., 2013), which calls for mechanistic exploration and studies using PES with high frequency and short duration or other parameters to avoid harmful changes.

\section{Perspectives}

Most research studies on PES were stalled after identification of specific signaling pathways involved, without elucidating the initiator molecule or initial conformational changes of biomolecules. Some studies have moved forward to identifying a complex array of signaling pathways involved, with the biological effects observed being just the outcome of multiple well-orchestrated processes. A comprehensive overview of biological mechanisms, as well as the corresponding physical stimuli involved, are needed to enable more extensive clinical applications by using novel toolkits. The target may be a protein subunit or some other molecular subunit that requires identification by high-throughput assays.

Integration with novel technology platforms is necessary to facilitate clinical applications of PES, i.e. high-throughput screening, microfluidics platforms, single-cell analysis, and bioinformatics. Novel technologies such as nsPEFs, which could precisely trigger specific activities within the cell and organelle internally, should be further investigated. PES with different parameters induces variable effects on different organelles, which in turn elicit variable biological effects on cells, tissues, and organs. The specific parameters of PES will depend on the clinical conditions of individual patients, different tissue states, and cell-types. Therefore, utilizing PES with appropriate parameters, such as specific stimulation frequencies and specific durations, must be optimized and standardized by high-throughput assays and www.ecmjournal.org 


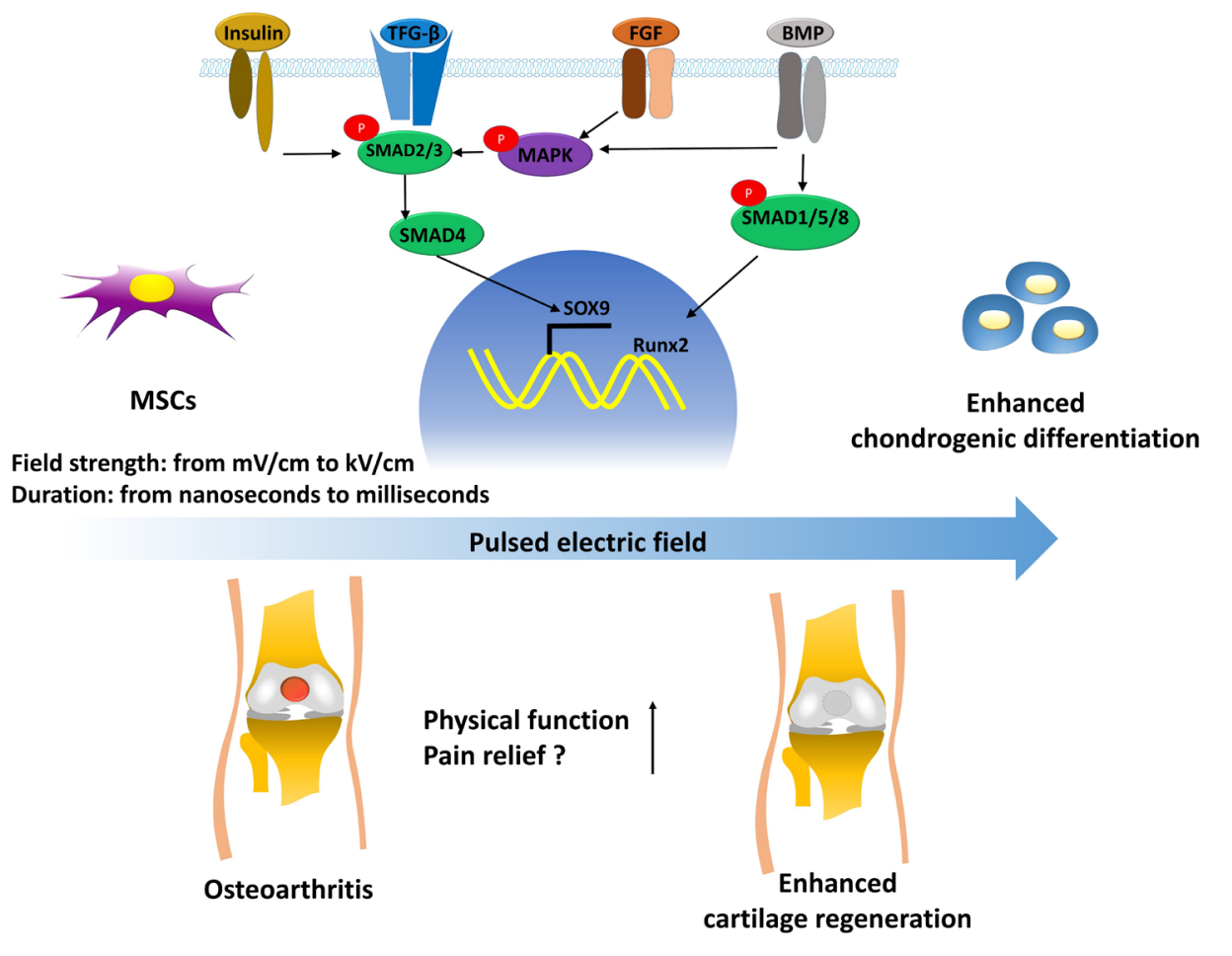

Fig. 4. Possible signalling pathways induced by PES during chondrogenic differentiation of MSCs. Parameters: field strength could range from $\mathrm{mV} / \mathrm{cm}$ to $\mathrm{kV} / \mathrm{cm}$. Duration could range from ns to $\mathrm{ms}$.

Field strength: from $\mathrm{mV} / \mathrm{cm}$ to $\mathrm{kV} / \mathrm{cm}$ chondrogenic differentiation 
human osteoarthritic cartilage explants. J Bone Joint Surg Am 90: 833-848.

Brighton CT, Wang W, Clark CC (2006) Upregulation of matrix in bovine articular cartilage explants by electric fields. Biochem Biophys Res Commun 342: 556-561.

Brighton CT, Wang W, Seldes R, Zhang GH, Pollack SR (2001) Signal transduction in electrically stimulated bone cells. J Bone Joint Surg Am 83: 15141523.

Buyong MR, Yunas J, Hamzah AA, Majlis BY, Larki F, Aziz NA (2015) Design, fabrication and characterization of dielectrophoretic microelectrode array for particle capture. Microelectronics International 32: 96-102.

Cameron MA, Al Abed A, Buskila Y, Dokos S, Lovell NH, Morley JW (2017) Differential effect of brief electrical stimulation on voltage-gated potassium channels. J Neurophysiol 117: 2014-2024.

Casciola M, Xiao S, Pakhomov AG (2017) Damagefree peripheral nerve stimulation by 12-ns pulsed electric field. Sci Rep 7: 10453. DOI: 10.1038/s41598017-10282-5.

Çelik ME, Karagöz İ (2014) The effect of the electrical stimulation on temperature rise in the retinal tissue for visual prostheses. IJCEE 6: 369-372.

Cemazar J, Miklavcic D, Kotnik T (2013) Microfluidic devices for manipulation, modification and characterization of biological cells in electric fields - a review. Informacije Midem-Ljubljana 43: 143-161.

Chao E, Inoue N (2003) Biophysical stimulation of bone fracture repair, regeneration and remodelling. Eur Cell Mater 6: 72-84.

Chen QQ, Zhang W, Chen XF, Bao YJ, Wang J, Zhu WZ (2012) Electrical field stimulation induces cardiac fibroblast proliferation through the calcineurin-NFAT pathway. Can J Physiol Pharmacol 90: 1611-1622.

Chen WJ, Xiong ZA, Zhang M, Yao CG, Zhao ZY, Hua YY, Zhou W (2013) Picosecond pulsed electric fields induce apoptosis in HeLa cells via the endoplasmic reticulum stress and caspase-dependent signaling pathways. Int J Oncol 42: 963-970.

Chen W (2005) Electroconformational denaturation of membrane proteins. Ann N Y Acad Sci 1066: 92-105.

Chen W (2004) Supra-physiological membrane potential induced conformational changes in $\mathrm{K}+$ channel conducting system of skeletal muscle fibers. Bioelectrochemistry 62: 47-56.

Chopinet L, Rols M-P (2015) Nanosecond electric pulses: a mini-review of the present state of the art. Bioelectrochemistry 103: 2-6.

Chung C, Burdick JA (2008) Engineering cartilage tissue. Adv Drug Deliv Rev 60: 243-262.

Ciombor DM, Aaron RK (2005) The role of electrical stimulation in bone repair. Foot Ankle Clin 10: 579-593.

Damaraju SM, Shen Y, Elele E, Khusid B, Eshghinejad A, Li J, Jaffe M, Arinzeh TL (2017) Threedimensional piezoelectric fibrous scaffolds selectively promote mesenchymal stem cell differentiation. Biomaterials 149: 51-62.

de Oliveira Melo M, Pompeo KD, Baroni BM, Vaz MA (2016) Effects of neuromuscular electrical stimulation and low-level laser therapy on neuromuscular parameters and health status in elderly women with knee osteoarthritis: a randomized trial. J Rehabil Med 48: 293-299.

de Vries-van Melle ML, Tihaya MS, Kops N, Koevoet W, Murphy JM, Verhaar J, Alini M, Eglin D, van Osch G (2014) Chondrogenic differentiation of human bone marrow-derived mesenchymal stem cells in a simulated osteochondral environment is hydrogel dependent. Eur Cell Mater 27: 112-123.

Deng J, Schoenbach KH, Buescher ES, Hair PS, Fox PM, Beebe SJ (2003) The effects of intense submicrosecond electrical pulses on cells. Biophysical J 84: 2709-2714.

Diekman BO, Rowland CR, Lennon DP, Caplan AI, Guilak F (2009) Chondrogenesis of adult stem cells from adipose tissue and bone marrow: induction by growth factors and cartilage-derived matrix. Tissue Eng Part A 16: 523-533.

Ebrahim S, Mollon B, Bance S, Busse JW, Bhandari M (2014) Low-intensity pulsed ultrasonography versus electrical stimulation for fracture healing: a systematic review and network meta-analysis. Can J Surg 57: E105-118.

Esfandiari E, Roshankhah S, Mardani M, Hashemibeni B, Naghsh E, Kazemi M, Salahshoor M (2014) The effect of high frequency electric field on enhancement of chondrogenesis in human adiposederived stem cells. Iran J Basic Med Sci 17: 571-576.

Estes BT, Diekman BO, Gimble JM, Guilak F (2010) Isolation of adipose-derived stem cells and their induction to a chondrogenic phenotype. Nat Protoc 5: 1294-1311.

Farr J, Mont MA, Garland D, Caldwell JR, Zizic TM (2006) Pulsed electrical stimulation in patients with osteoarthritis of the knee: follow up in 288 patients who had failed non-operative therapy. Surg Technol Int 15: 227-233.

Fary RE, Briffa NK, Briffa TG (2009) Effectiveness of pulsed electrical stimulation in the management of osteoarthritis of the knee: three case reports. Physiother Theory Pract 25: 21-29.

Fary RE, Carroll GJ, Briffa TG, Briffa NK (2011) The effectiveness of pulsed electrical stimulation in the management of osteoarthritis of the knee results of a double-blind, randomized, placebo-controlled, repeated-measures trial. Arthritis Rheum 63: 13331342.

Fary RE, Carroll GJ, Briffa TG, Gupta R, Briffa NK (2008) The effectiveness of pulsed electrical stimulation (E-PES) in the management of osteoarthritis of the knee: a protocol for a randomised controlled trial. BMC Musculoskelet Disord 9: 18. DOI: 10.1186/14712474-9-18.

Fitzsimmons RJ, Gordon SL, Kronberg J, Ganey T, Pilla AA (2008) A pulsing electric field (PEF) 
increases human chondrocyte proliferation through a transduction pathway involving nitric oxide signaling. J Orthop Res 26: 854-859.

Fricke H (1953) The electric permittivity of a dilute suspension of membrane-covered ellipsoids. J Appl Phys 24: 644-646.

Garland D, Holt P, Harrington JT, Caldwell J, Zizic T, Cholewczynski J (2007) A 3-month, randomized, double-blind, placebo-controlled study to evaluate the safety and efficacy of a highly optimized, capacitively coupled, pulsed electrical stimulator in patients with osteoarthritis of the knee. Osteoarthritis Cartilage 15: 630-637.

Gigo-Benato D, Russo TL, Geuna S, Santa Rosa Domingues NR, Salvini TF, Parizotto NA (2010) Electrical stimulation impairs early functional recovery and accentuates skeletal muscle atrophy after sciatic nerve crush injury in rats. Muscle Nerve 41: 685-693.

Griffin M, Bayat A (2011) Electrical stimulation in bone healing: critical analysis by evaluating levels of evidence. Eplasty 11: e34.

Guilak F, Estes BT, Diekman BO, Moutos FT, Gimble JM (2010) 2010 Nicolas Andry Award: multipotent adult stem cells from adipose tissue for musculoskeletal tissue engineering. Clin Orthop Relat Res 468: 2530-2540.

Hall Eh, Schoenbach Kh, Beebe S (2007) Nanosecond pulsed electric fields induce apoptosis in p53-wildtype and p53-null HCT116 colon carcinoma cells. Apoptosis 12:1721-1731.

Haddad JB, Obolensky AG, Shinnick P (2007) The biologic effects and the therapeutic mechanism of action of electric and electromagnetic field stimulation on bone and cartilage: new findings and a review of earlier work. J Altern Complement Med 13: 485-490.

Hayashi H, Edin F, Li H, Liu W, Rask-Andersen $\mathrm{H}$ (2016) The effect of pulsed electric fields on the electrotactic migration of human neural progenitor cells through the involvement of intracellular calcium signaling. Brain Research 1652: 195-203.

Hirt MN, Boeddinghaus J, Mitchell A, Schaaf S, Börnchen C, Müller C, Schulz H, Hubner N, Stenzig J, Stoehr A (2014) Functional improvement and maturation of rat and human engineered heart tissue by chronic electrical stimulation. J Mol Cell Cardiol 74: 151-161.

Holt PA, Ozyurekoglu T, Deveshwar S, Maclaughlin EJ, Khlopas A, Mont MA, Pang SW, Tuber JS, Schechtman J, Zizic TM (2018) A pulsed electrical joint stimulator for the treatment of osteoarthritis of the hand and wrist. Orthopedics 41: e550-e556.

Hua YY, Wang XS, Zhang Y, Yao CG, Zhang XM, Xiong ZA (2012) Intense picosecond pulsed electric fields induce apoptosis through a mitochondrialmediated pathway in HeLa cells. Mol Med Rep 5: 981-987.

Hui SW, Stenger DA (1993) Electrofusion of cells: hybridoma production by electrofusion and polyethylene glycol. Methods in Enzymology 220: 212-227.

Johnson MI, Tabasam G (2003) A single-blind investigation into the hypoalgesic effects of different swing patterns of interferential currents on coldinduced pain in healthy volunteers.Arch Phys Med Rehabil 84: 350-357.

Johnstone B, Alini M, Cucchiarini M, Dodge GR, Eglin D, Guilak F, Madry H, Mata A, Mauck RL, Semino CE (2013) Tissue engineering for articular cartilage repair - the state of the art. Eur Cell Mater 25: 248-256.

Jordan CA, Neumann E, Sowers AE (2013) Electroporation and electrofusion in cell biology. Springer Science \& Business Media. New York, pp: 208-220.

Jünger M, Zuder D, Steins A, Hahn M, Klyscz T (1997) Treatment of venous ulcers with low frequency pulsed current (Dermapulse): effects on cutaneous microcirculation. Hautarzt 48: 897-903.

Kern H, Barberi L, Lofler S (2016) Electrical stimulation counteracts muscle decline in seniors. Front Aging Neurosci 6: 189. DOI: 10.3389/ fnagi.2014.00189.

Khang D, Park GE, Webster TJ (2008) Enhanced chondrocyte densities on carbon nanotube composites: the combined role of nanosurface roughness and electrical stimulation. J Biomed Mater Res A 86: 253260.

Kirawanich P, Pausawasdi N, Srisawat C, Yakura SJ, Islam NE (2010) An FDTD interaction scheme of a high-intensity nanosecond-pulsed electric-field system for in vitro cell apoptosis applications. IEEE 38: 2574-2582.

Kotnik T, Frey W, Sack M, Meglič SH, Peterka M, Miklavčič D (2015) Electroporation-based applications in biotechnology. Trends Biotechnol 33: 480-488.

Kwon HJ, Lee GS, Chun H (2016) Electrical stimulation drives chondrogenesis of mesenchymal stem cells in the absence of exogenous growth factors. Sci Rep 6: 39302. DOI: 10.1038/srep39302.

Leal CL, Liu L (1998) Differential effects of kinase inhibitor and electrical stimulus on activation and histone H1 kinase activity in pig oocytes. Anim Reprod Sci 52: 51-61.

Li L, Dai Y, Xia R, Chen S, Qiao D (2005) Pulsed electric field exposure of insulin induces anti-proliferative effects on human hepatocytes. Bioelectromagnetics 26: 639-647.

Liu Q, Song B (2014) Electric field regulated signaling pathways. Int J Biochem Cell Biol 55: 264268.

Mardani M, Roshankhah S, Hashemibeni B, Salahshoor M, Naghsh E, Esfandiari E (2016) Induction of chondrogenic differentiation of human adipose-derived stem cells by low frequency electric field. Adv Biomed Res 5: 97. DOI: 10.4103/22779175.183146.

Massari L, Benazzo F, De MM, Setti S, Fini M (2007) Effects of electrical physical stimuli on articular cartilage. J Bone Joint Surg Am 89 Suppl 3: 152-161. 
Matsumoto M, Imura T, Fukazawa T, Sun Y, Takeda M, Kajiume T, Kawahara Y, Yuge L (2013) Electrical stimulation enhances neurogenin2 expression through beta-catenin signaling pathway of mouse bone marrow stromal cells and intensifies the effect of cell transplantation on brain injury. Neurosci Lett 533: 71-76.

Melo Mde O, Pompeo KD, Brodt GA, Baroni BM, da Silva Junior DP, Vaz MA (2015) Effects of neuromuscular electrical stimulation and lowlevel laser therapy on the muscle architecture and functional capacity in elderly patients with knee osteoarthritis: a randomized controlled trial. Clin Rehabil 29: 570-580.

Meraviglia V, Azzimato V, Colussi C, Florio MC, Binda A, Panariti A, Qanud K, Suffredini S, Gennaccaro L, Miragoli M (2015) Acetylation mediates Cx43 reduction caused by electrical stimulation. J Mol Cell Cardiol 87: 54-64.

Morino S, Kondo T, Sasaki K, Adachi H, Suico MA, Sekimoto E, Matsuda T, Shuto T, Araki E, Kai $\mathrm{H}$ (2008) Mild electrical stimulation with heat shock ameliorates insulin resistance via enhanced insulin signaling. PloS One 3: e4068. DOI: 10.1371/journal. pone.0004068.

Moro E, Esselink R, Xie J, Hommel M, Benabid A, Pollak P (2002) The impact on Parkinson's disease of electrical parameter settings in STN stimulation. Neurology 59: 706-713.

Morotomi-Yano K, Akiyama H, Yano K (2011a) Nanosecond pulsed electric fields activate MAPK pathways in human cells. Arch Biochem Biophys 515: 99-106.

Morotomi-Yano K, Uemura Y, Katsuki S, Akiyama H, Yano K (2011b) Activation of the JNK pathway by nanosecond pulsed electric fields. Biochem Biophys Res Commun 408: 471-476.

Murata Y, Iwasaki H, Sasaki M, Inaba K, Okamura Y (2005) Phosphoinositide phosphatase activity coupled to an intrinsic voltage sensor. Nature 435: 1239-1243.

Nature Methods (2006) Transfection of mammalian cells by electroporation. Nature Methods 3: 67-68.

Negm A, Lorbergs A, Macintyre N (2013) Efficacy of low frequency pulsed subsensory threshold electrical stimulation $v$ s placebo on pain and physical function in people with knee osteoarthritis: systematic review with meta-analysis. Osteoarthritis Cartilage 21: 1281-1289.

Nesin V, Bowman AM, Xiao S, Pakhomov AG (2012) Cell permeabilization and inhibition of voltagegated $\mathrm{Ca} 2+$ and $\mathrm{Na}+$ channel currents by nanosecond pulsed electric field. Bioelectromagnetics 33: 394-404.

Ning T, Guo J, Zhang K, Li K, Zhang J, Yang Z, Ge Z (2019) Nanosecond pulsed electric fields enhanced chondrogenic potential of mesenchymal stem cells via JNK/CREB-STAT3 signaling pathway. Stem Cell Res Ther 10: 45. DOI: 10.1186/s13287-019-1133-0.

Okino M, Mohri H (1987) Effects of a high-voltage electrical impulse and an anticancer drug on in vivo growing tumors. Jpn J Cancer Res 78: 1319-1321.
Pakhomov AG, Gianulis E, Vernier PT, Semenov I, Xiao S, Pakhomova ON (2015) Multiple nanosecond electric pulses increase the number but not the size of long-lived nanopores in the cell membrane. Biochim Biophys Acta 1848: 958-966.

Pakhomov AG, Xiao S, Pakhomova ON, Semenov I, Kuipers MA, Ibey BL (2014) Disassembly of actin structures by nanosecond pulsed electric field is a downstream effect of cell swelling. Bioelectrochemistry 100: 88-95.

Pakhomova ON, Gregory BW, Semenov I, Pakhomov AG (2013) Two modes of cell death caused by exposure to nanosecond pulsed electric field. PLoS One 8: e70278. DOI: 10.1371/journal.pone.0070278.

Pakhomova ON, Khorokhorina VA, Bowman AM, Rodaitė-Riševičienė R, Saulis G, Xiao S, Pakhomov AG (2012) Oxidative effects of nanosecond pulsed electric field exposure in cells and cell-free media. Arch Biochem Biophys 527: 55-64.

Perdisa F, Gostyńska N, Roffi A, Filardo G, Marcacci M, Kon E (2015) Adipose-derived mesenchymal stem cells for the treatment of articular cartilage: a systematic review on preclinical and clinical evidence. Stem Cells Int 2015: 597652. DOI: 10.1155/2015/597652

Polidori P, Lee S, Kauffman RG, Marsh BB (1999) Low voltage electrical stimulation of lamb carcasses: effects on meat quality. Meat Science 53: 179-182.

Qin S, Yin H, Yang C, Dou Y, Liu Z, Zhang P, Yu H, Huang Y, Feng J, Hao J, Hao J, Deng L, Yan X, Dong $X$, Zhao Z, Jiang T, Wang HW, Luo SJ, Xie C (2016) A magnetic protein biocompass. Nat Mater 15: 217-226.

Rems L, Miklavčič D, Pucihar G (2014) Induced transmembrane voltage during cell electrofusion using nanosecond electric pulses. In: Roa Romero L. (eds) XIII Mediterranean Conference on Medical and Biological Engineering and Computing 2013. IFMBE Proceedings, 41. Springer, Cham, pp: 896-899.

Rems L, Ušaj M, Kandušer M, Reberšek M, Miklavčič D, Pucihar G (2013) Cell electrofusion using nanosecond electric pulses. Sci Rep 3: 3382. DOI: 10.1038/srep03382.

Rossini P, Burke D, Chen R, Cohen L, Daskalakis Z, Di Iorio R, Di Lazzaro V, Ferreri F, Fitzgerald P, George M (2015) Non-invasive electrical and magnetic stimulation of the brain, spinal cord, roots and peripheral nerves: basic principles and procedures for routine clinical and research application. An updated report from an I.F.C.N. Committee. Clin Neurophysiol 126: 1071-1107.

Rouabhia M, Park H, Meng S, Derbali H, Zhang Z (2013) Electrical stimulation promotes wound healing by enhancing dermal fibroblast activity and promoting myofibroblast transdifferentiation. PLoS One 8: e71660. DOI: 10.1371/journal.pone.0071660.

Schoellhammer CM, Blankschtein D, Langer R (2014) Skin permeabilization for transdermal drug delivery: recent advances and future prospects. Expert Opin Drug Deliv 11: 393-407.

Schoenbach KH (2018) From the basic science of biological effects of ultrashort electrical pulses to medical therapies. Bioelectromagnetics 39: 257-276. 
Schoenbach KH, Hargrave SJ, Joshi RP, Kolb JF, Nuccitelli R, Osgood C, Pakhomov A, Stacey M, Swanson RJ, White JA (2007) Bioelectric effects of intense nanosecond pulses. IEEE 14: 1088-1109.

Schoenbach KH, Joshi RP, Kolb JF, Chen N, Stacey M, Blackmore PF, Buescher ES, Beebe SJ (2004) Ultrashort electrical pulses open a new gateway into biological cells. IEEE 92: 1122-1137.

Schwan HP (1956) Electrical properties of tissue and cell suspensions. Adv Biol Med Phys 5: 147-209.

Semenov I, Xiao S, Pakhomov AG (2013) Primary pathways of intracellular Ca2+ mobilization by nanosecond pulsed electric field. Biochim Biophys Acta 1828: 981-989.

Soba A, Suárez C, González MM, Cabrales LEB, Pupo AEB, Reyes JB, Tassé JPM (2018) Integrated analysis of the potential, electric field, temperature, $\mathrm{pH}$ and tissue damage generated by different electrode arrays in a tumor under electrochemical treatment. Math Comput Simul 146: 160-176.

Sobrino-López A, Martín-Belloso O (2010) Review: potential of high-intensity pulsed electric field technology for milk processing. Food Eng Rev 2: 1727.

Somoza RA, Welter JF, Correa D, Caplan AI (2014) Chondrogenic differentiation of mesenchymal stem cells: challenges and unfulfilled expectations. Tissue Eng Part B Rev 20: 596-608.

Tang X, Fan L, Pei M, Zeng L, Ge Z (2015) Evolving concepts of chondrogenic differentiation: history, state-of-the-art and future perspectives. Eur Cell Mater 30: 12-27.

Teissie J, Tsong TY (1980) Evidence of voltageinduced channel opening in Na-K ATPase of humanerythrocyte membrane. J Membr Biol 55: 133-140.

Toepfl S, Mathys A, Heinz V, Knorr D (2006) Potential of high hydrostatic pressure and pulsed electric fields for energy efficient and environmentally friendly food processing. Food Reviews International 22: 405-423.

Tolstykh G, Beier H, Thompson G, Roth C, Ibey B (2013) Nanosecond pulsed electric fields activate intracellular signaling pathways. SPIE Newsroom. DOI: $10.1117 / 2.1201302 .004736$.

Ud-Din S, Bayat A (2014) Electrical stimulation and cutaneous wound healing: a review of clinical evidence. Healthcare (Basel) 2: 445-467.

Ud-Din S, Sebastian A, Giddings P, Colthurst J, Whiteside S, Morris J, Nuccitelli R, Pullar C, Baguneid M, Bayat A (2015) Angiogenesis is induced and wound size is reduced by electrical stimulation in an acute wound healing model in human skin. PLoS One 10: e0124502. DOI: 10.1371/journal.pone.0124502.

Uzieliene I, Bernotas P, Mobasheri A, Bernotiene E (2018) The role of physical stimuli on calcium channels in chondrogenic differentiation of mesenchymal stem cells. Int J Mol Sci 19: E2998. DOI: 10.3390/ ijms19102998.

Vasilkoski Z, Esser AT, Gowrishankar T, Weaver JC (2006) Membrane electroporation: the absolute rate equation and nanosecond time scale pore creation. Phys Rew E 74: 021904.

Vernier PT, Sun YH, Marcu L, Salemi S, Craft CM, Gundersen MA (2003) Calcium bursts induced by nanosecond electric pulses. Biochem Biophys Res Commun 310: 286-295.

Voldman J (2006) Electrical forces for microscale cell manipulation. Annu Rev Biomed Eng 8: 425-454.

Wang W, Wang ZY, Zhang GH, Clark CC, Brighton CT (2004) Up-regulation of chondrocyte matrix genes and products by electric fields. Clin Orthop Relat Res 427 Suppl: S163-173.

Wang X, Li Y, He X, Chen S, Zhang JZ (2014) Effect of strong electric field on the conformational integrity of insulin. J Phys Chem A 118: 8942-8952.

Wang Y, Rouabhia M, Lavertu D, Zhang Z (2017) Pulsed electrical stimulation modulates fibroblasts' behaviour through the Smad signalling pathway. J Tissue Eng Regen Med 11: 1110-1121.

Weaver JC, Smith KC, Esser AT, Son RS, Gowrishankar T (2012) A brief overview of electroporation pulse strength-duration space: a region where additional intracellular effects are expected. Bioelectrochemistry 87: 236-243.

Weaver JC, Vaughan TE, Martin GT (1999) Biological effects due to weak electric and magnetic fields: the temperature variation threshold. Biophys J 76: 3026-3030.

Weinberg SH (2013) High-frequency stimulation of excitable cells and networks. PLoS One 8: e81402. DOI: 10.1371/journal.pone.0081402.

Xu J, Wang W, Clark CC, Brighton CT (2009) Signal transduction in electrically stimulated articular chondrocytes involves translocation of extracellular calcium through voltage-gated channels. Osteoarthritis Cartilage 17: 397-405.

Yamada M, Tanemura K, Okada S, Iwanami A, Nakamura M, Mizuno H, Ozawa M, Ohyama-Goto R, Kitamura N, Kawano M (2007) Electrical stimulation modulates fate determination of differentiating embryonic stem cells. Stem Cells 25: 562-570.

Yang E, Li J, Cho M, XiaoS (2018) Cell fragmentation and permeabilization by a $1 \mathrm{~ns}$ pulse driven triplepoint electrode. Biomed Res Int 2018: 4072983. DOI: 10.1155/2018/4072983.

Yao C, Hu X, Mi Y, Li C, Sun C (2009) Window effect of pulsed electric field on biological cells. IEEE 16: 1259-1266.

Yarmush ML, Golberg A, Sersa G, Kotnik T, Miklavcic D (2014) Electroporation-based technologies for medicine: principles, applications, and challenges. Annu Rev Biomed Eng 16: 295-320.

Yogesh K (2016) Pulsed electric field processing of egg products: a review. J Food Sci Technol 53: 934-945.

Yu X, McGraw PA, House FS, Crowe JE, Jr. (2008) An optimized electrofusion-based protocol for generating virus-specific human monoclonal antibodies. J Immunol Methods 336: 142-151.

Yuan X, Arkonac DE, Chao P-hG, VunjakNovakovic G (2014) Electrical stimulation enhances 
cell migration and integrative repair in the meniscus. Sci Rep 4: 3674. DOI: 10.1038/srep03674

Zeng C, Yang T, Deng Z-h, Yang Y, Zhang Y, Lei G-h (2015) Electrical stimulation for pain relief in knee osteoarthritis: systematic review and network meta-analysis. Osteoarthritis Cartilage 23: 189-202.

Zhang K, Guo J, Ge Z, Zhang J (2014) Nanosecond pulsed electric fields (nsPEFs) regulate phenotypes of chondrocytes through Wnt/ $\beta$-catenin signaling pathway. Sci Rep 4: 5836. DOI: 10.1038/srep05836.

Zhang X, Ren W, DeCaen P, Yan C, Tao X, Tang L, Wang J, Hasegawa K, Kumasaka T, He J (2012) Crystal structure of an orthologue of the NaChBac voltage-gated sodium channel. Nature 486: 130-134.

Zhao M, Song B, Pu J, Wada T, Reid B, Tai G, Wang F, Guo A, Walczysko P, Gu Y, Sasaki T, Suzuki
A, Forrester JV, Bourne HR, Devreotes PN, McCaig CD, Penninger JM (2006) Electrical signals control wound healing through phosphatidylinositol-3-OH kinase-gamma and PTEN. Nature 442: 457-460.

Zimmermann U (1986) Electrical breakdown, electropermeabilization and electrofusion. Rev Physiol Biochem Pharmacol 105: 175-256.

Editor's note: All comments/questions by the reviewers were answered by making changes in the text. Hence, there is no Discussion with Reviewers section.

The Scientific Editor responsible for this paper was Christine Hartmann. 